Article

\title{
Cobalt carbonyl ionic liquids based on the 1,1,3,3-tetra-alkylguanidine cation: Novel, highly efficient, and reusable catalysts for the carbonylation of epoxides
}

\author{
Wei Zhang a,b, Feng Han a, Jin Tong a , Chungu Xia a , Jianhua Liu a,* \\ a State Key Laboratory for Oxo Synthesis and Selective Oxidation, Lanzhou Institute of Chemical Physics, Chinese Academy of Sciences, Lanzhou 730000, \\ Gansu, China \\ b University of Chinese Academy of Sciences, Beijing 100049, China
}

\section{A R T I C L E I N F O}

\section{Article history:}

Received 26 January 2017

Accepted 23 March 2017

Published 5 May 2017

\section{Keywords:}

Cobalt carbonyl ionic liquid

Carbonylation

Epoxide

Tetra-alkylguanidine

Recyclability

\begin{abstract}
A B S T R A C T
A series of novel cobalt carbonyl ionic liquids based on 1,1,3,3-tetra-alkyl-guanidine, such as [1,1-dimethyl-3,3-diethylguanidinium] $\left[\mathrm{Co}(\mathrm{CO})_{4}\right] \quad$ (3a), [1,1-dimethyl-3,3-dibutylguanidinium] $\left[\mathrm{Co}(\mathrm{CO})_{4}\right]$ (3b), [1,1-dimethyl-3,3-tetramethyleneguanidinium] $\left[\mathrm{Co}(\mathrm{CO})_{4}\right]$ (3c), and [1,1-dimethyl-3,3-pentamethyleneguanidinium] $\left[\mathrm{Co}(\mathrm{CO})_{4}\right](3 \mathbf{d})$, were synthesized in good yields and were also characterized using infrared spectroscopy, ultraviolet-visible spectroscopy, ${ }^{1} \mathrm{H}$ nuclear magnetic resonance (NMR) spectroscopy, ${ }^{13} \mathrm{C}$ NMR spectroscopy, high-resolution mass spectrometry, differential scanning calorimetry, and thermogravimetric analysis. The four compounds exhibited high thermal and chemical stability. In addition, the catalytic performance of these compounds was investigated in the carbonylation of epoxides, with 3a exhibiting the best catalytic activity without the aid of a base as the additive. The catalyst could be reused at least six times without significant decreases of the selectivity or conversion rate. Moreover, the catalyst system exhibited good tolerance with terminal epoxides bearing alkyl, alkenyl, aryl, alkoxy, and chloromethyl functional groups.
\end{abstract}

(C) 2017, Dalian Institute of Chemical Physics, Chinese Academy of Sciences.

Published by Elsevier B.V. All rights reserved.

\section{Introduction}

Ionic liquids (ILs), such as organic salts consisting of an organic cation and an inorganic or organic anion, have attracted considerable attention because of their unique properties, such as negligible vapor pressure and high thermal, chemical, and electrochemical stability [1-6]. In addition, the structure and properties of ILs can be modified by varying the nature of the anions and cations [7]. Recently, among the vast research related to ILs, organometallic ILs [8-12] based on transition metals have received increasing attention, especially in catalysis $[5,13]$, because of their potential catalytic activity and considerable reusability $[11,14]$. Notably, $\mathrm{Co}(\mathrm{CO})_{4}{ }^{-}$as a widely used catalytic active species has been used in organometallic ILs [11,15-21]. For example, the compounds [bmim] [Co(CO)4] (bmim = 1-butyl-3-methylimidazolium), $[\mathrm{CnPy}]\left[\mathrm{Co}(\mathrm{CO})_{4}\right]$ ( $\mathrm{CnPy}=N-\mathrm{C}_{n} \mathrm{H}_{2 n+1}$ pyridinium), [methylguanidinium] $\left[\mathrm{Co}(\mathrm{CO})_{4}\right]$ and [tetramethylguanidinium] $\left[\mathrm{Co}(\mathrm{CO})_{4}\right]$ have been investigated by researchers [11,22-26]. According to the previous reports, $[\mathrm{CnPy}]\left[\mathrm{Co}(\mathrm{CO})_{4}\right]$ and $[\mathrm{bmim}]\left[\mathrm{Co}(\mathrm{CO})_{4}\right]$ organometallic ILs have been applied in the carbonylation of epoxides. However, the stability and reusability of this type of catalyst could be further enhanced.

Guanidinium offers many significant and advantageous features because of its structural characteristics. The guanidinium cation can act as a hydrogen bond donor because of the pres-

\footnotetext{
* Corresponding author. Tel: +86-931-4968286; Fax: +86-931-8277088; E-mail: jhliu@licp.cas.cn

This work was supported by the National Natural Science Foundation of China $(21373248,21673260,21133011)$.

DOI: 10.1016/S1872-2067(17)62824-9 | http://www.sciencedirect.com/science/journal/18722067 | Chin. J. Catal., Vol. 38, No. 5, May 2017
} 
ence of substituted hydrogen of the $\mathrm{N}$ atom and $\mathrm{N}$-alkyl substituents, which can somehow stabilize the $\mathrm{Co}(\mathrm{CO})_{4}{ }^{-}$anion and activate an epoxide [22,28]. Moreover, the guanidinium cationic plane structure can be modified by the action of relatively large alkyl substituents. Therefore, the $\mathrm{C}$ atom connected with the three $\mathrm{N}$ atoms presents an electron-deficient state. Thus, the cationic part can be regarded as a Lewis acid [29], which can assist the ring-opening process of the epoxides [23,30-32]. It is expected that cobalt carbonyl ILs based on 1,1,3,3-tetraalkylguanidine can play the dual role of stabilizing $\mathrm{Co}(\mathrm{CO})_{4}^{-}$ anions and activating epoxy compounds.

To verify our speculation, we designed and synthesized a series of cobalt carbonyl ILs based on 1,1,3,3-tetra-alkylguanidine (Scheme 1), which was applied in the carbonylation of epoxides. Notably, it was observed that 3a exhibited the best catalytic activity without the aid of a base as an additive as well as perfect recyclability.

\section{Experimental}

\subsection{General}

All the organometallic manipulations were performed in a glove box or under a $\mathrm{N}_{2}$ atmosphere using standard Schlenk techniques. Unless otherwise noted, all the reagents were of analytical grade and were used as received. Tetrahydrofuran (THF), dichloromethane, ethanol, and propylene oxide were purged with argon to eliminate the dissolved oxygen and were dried to remove water. $\mathrm{Co}_{2}(\mathrm{CO})_{8}$ was prepared by our research group according to the method described in a previous report [33]. Infrared (IR) spectra were recorded on a Bruker IFS120HR spectrophotometer. ${ }^{1} \mathrm{H}$ nuclear magnetic resonance (NMR) and ${ }^{13} \mathrm{C}$ NMR spectra were measured on Bruker Avance III $(400 \mathrm{MHz})$ spectrometers. High-resolution mass spectrometry (HRMS) analyses were performed on a Bruker Micro TOF-QII mass instrument with electrospray ionization (ESI) in the positive ionization and negative mode on samples dissolved in methanol. The glass transition temperature $\left(T_{\mathrm{g}}\right)$ was determined on a Mettler-Toledo differential scanning calorimeter (model DSC 822e) at a scan rate of $10{ }^{\circ} \mathrm{C} / \mathrm{min}$. The thermal decomposition temperature was characterized on a Netzsch STA449F3 thermogravimetric differential scanning calorimeter (TG-DSC) at a scan rate of $10^{\circ} \mathrm{C} / \mathrm{min}$.

\subsection{Synthesis of cobalt carbonyl ILs based on 1,1,3,3-tetra-alkylguanidine}

Compound 1 (1,1,3,3-tetra-alkylguanidine) was synthesized according to the method described in the Ref. [34] using dimethyl cyanamide and diamine as the starting materials. Moreo- ver, the structures of the products were confirmed by ${ }^{1} \mathrm{H} /{ }^{13} \mathrm{C}$ NMR.

Compound 2 was prepared via neutralization of 1,1,3,3-tetra-alkylguanidine with acids. In the experiment, $10.0 \mathrm{~mL}$ of ethanol and 1,1,3,3-tetra-alkylguanidine (10.0 mmol) were loaded into a $100-\mathrm{mL}$ flask in an ice water bath at $0{ }^{\circ} \mathrm{C}$. Then, $16.0 \mathrm{mmol}$ of $\mathrm{HCl}$ in $8.0 \mathrm{~mL}$ of ethanol was slowly added into the flask under stirring, and the stirring was continued for $4 \mathrm{~h}$. The reaction mixture was evaporated under reduced pressure. The concentrated mixture was then washed with ether, and the product was dried under vacuum at $50{ }^{\circ} \mathrm{C}$ for $24 \mathrm{~h}$. All the products were white solids, except for $\mathbf{2 b}$, which was a colorless viscous liquid. Moreover, ${ }^{1} \mathrm{H} /{ }^{13} \mathrm{C}$ NMR characterization data were obtained.

The 1,1,3,3-tetra-alkylguanidine cobalt carbonyl ILs (compounds 3a-3d) were synthesized by the reaction of $\mathrm{KCo}(\mathrm{CO})_{4}$ with 1,1,3,3-tetra-alkylguanidine chloride salts. A 50-mL Schlenk flask containing milled $\mathrm{KOH}(6.0 \mathrm{mmol})$ and $\mathrm{Co}_{2}(\mathrm{CO})_{8}$ $(1.0 \mathrm{mmol})$ was placed in the glove box. Then, $6.0 \mathrm{~mL}$ of degassed THF was slowly dripped into the flask under stirring, and the stirring was continued for $2 \mathrm{~h}$. Subsequently, the supernatant was transferred to another Schlenk flask containing 1.1 mmol 1,1,3,3-tetra-alkylguanidine chloride salt. The reaction was continued for $8 \mathrm{~h}$ under stirring. The THF solvent was

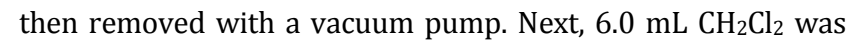
added into the flask under an Ar atmosphere. Afterward, the mixture was filtered under an Ar atmosphere, and the solvent was removed in vacuo to obtain the desired products $\mathbf{3}$ as light or dark-blue viscous oily liquids. The 1,1,3,3-tetra-alkylguanidine cobalt carbonyl ILs were all characterized using IR, ultraviolet-visible (UV-Vis) spectroscopy, ${ }^{1} \mathrm{H}$ NMR, ${ }^{13} \mathrm{C}$ NMR, HRMS (ESI), TG-DSC, and DSC.

\subsection{Characterization data for cobalt carbonyl ILs based on 1,1,3,3-tetra-alkylguanidine}

3a $0.27 \mathrm{~g}, 86 \%$; $T_{\mathrm{g}}$ : $-77^{\circ} \mathrm{C}$; thermal decomposition temperature: $215^{\circ} \mathrm{C}$; selected $v_{\max } / \mathrm{cm}^{-1}(\mathrm{KBr}) 1882$ vs $\left(\mathrm{Co}(\mathrm{CO}){ }_{4}{ }^{-}\right) ;{ }^{1} \mathrm{H}$ NMR (400 MHz, DMSO-d6): $\delta 7.93(\mathrm{~s}, 2 \mathrm{H}), 3.27(\mathrm{q}, J=7.1 \mathrm{~Hz}$, $4 \mathrm{H}), 2.90(\mathrm{~s}, 6 \mathrm{H}), 1.10(\mathrm{t}, J=7.1 \mathrm{~Hz}, 6 \mathrm{H}) ;{ }^{13} \mathrm{C}$ NMR $(100 \mathrm{MHz}$, DMSO- $d_{6}$ ): $\delta 160.6,43.1,39.4,12.5$; HRMS (ESI) positive ion: $m / z$ 144.1488 $\left(\mathrm{C}_{7} \mathrm{H}_{18} \mathrm{~N}_{3}{ }^{+}\right)$; HRMS (ESI) negative ion: $m / z$ $170.9135 \quad\left(\mathrm{Co}(\mathrm{CO})_{4}^{-}\right), \quad 142.9199 \quad\left(\mathrm{Co}(\mathrm{CO})_{3}{ }^{-}\right), \quad 114.9254$ $\left(\mathrm{Co}(\mathrm{CO})_{2}{ }^{-}\right)$.

3b 0.30 g, $81 \%$; $\mathrm{Tg}_{\mathrm{g}}-65^{\circ} \mathrm{C}$; thermal decomposition temperature: $207^{\circ} \mathrm{C}$; selected $v_{\max } / \mathrm{cm}^{-1}(\mathrm{KBr}) 1886$ vs $\left(\mathrm{Co}(\mathrm{CO})_{4}^{-}\right) ;{ }^{1} \mathrm{H}$ NMR (400 MHz, DMSO- $\left.d_{6}\right): \delta 7.96(\mathrm{~s}, 2 \mathrm{H}), 3.20(\mathrm{t}, J=7.0 \mathrm{~Hz}$, $4 \mathrm{H}), 2.89(\mathrm{~s}, 6 \mathrm{H}), 1.54-1.39(\mathrm{~m}, 4 \mathrm{H}), 1.23(\mathrm{dt}, J=14.8,7.5 \mathrm{~Hz}$, $4 \mathrm{H}), 0.87(\mathrm{t}, J=7.3 \mathrm{~Hz}, 6 \mathrm{H}) ;{ }^{13} \mathrm{C}$ NMR (100 MHz, DMSO- $\left.d_{6}\right): \delta$ 161.1, 48.2, 39.3, 28.8, 19.1, 13.5; HRMS (ESI) positive ion: $m / z$

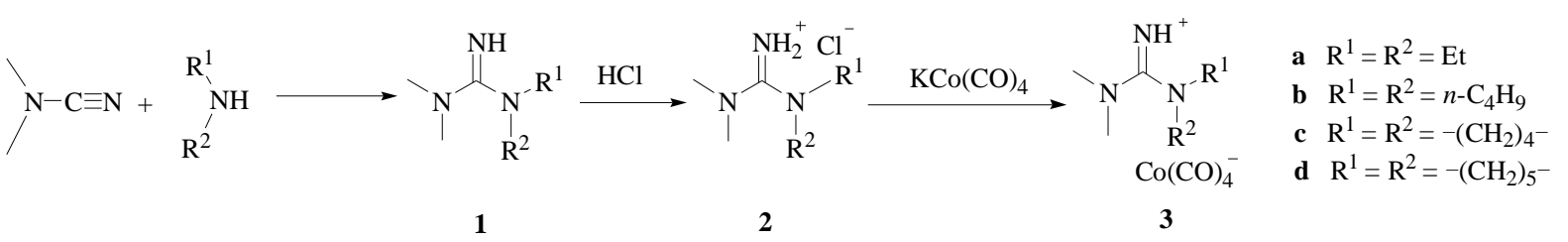

Scheme 1. Synthetic routes and structures of 1,1,3,3-tetra-alkylguanidine cobalt carbonyl ILs. 
$200.2120\left(\mathrm{C}_{11} \mathrm{H}_{26} \mathrm{~N}_{3}{ }^{+}\right)$; HRMS (ESI) negative ion: $m / z 170.9135$ $\left(\mathrm{Co}(\mathrm{CO})_{4}^{-}\right), 142.9203\left(\mathrm{Co}(\mathrm{CO})_{3}{ }^{-}\right), 114.9254\left(\mathrm{Co}(\mathrm{CO})_{2}^{-}\right)$.

3c $0.25 \mathrm{~g}$, 80\%; $T_{\mathrm{g}}$ : $-60{ }^{\circ} \mathrm{C}$; thermal decomposition temperature: $208{ }^{\circ} \mathrm{C}$; selected $v_{\max } / \mathrm{cm}^{-1}(\mathrm{KBr}) 1882$ vs (Co(CO) $\left.{ }^{-}\right) ;{ }^{1} \mathrm{H}$ NMR (400 MHz, DMSO-d6): $\delta 7.62(\mathrm{~s}, 2 \mathrm{H}), 3.39(\mathrm{t}, J=6.4 \mathrm{~Hz}$, $4 \mathrm{H}), 2.91(\mathrm{~s}, 6 \mathrm{H}), 1.86(\mathrm{dd}, J=7.8,5.1 \mathrm{~Hz}, 4 \mathrm{H}) ;{ }^{13} \mathrm{C}$ NMR $(100$ MHz, DMSO- $d_{6}$ ): $\delta$ 158.1, 49.2, 39.4, 24.9; HRMS (ESI) positive ion: $m / z$ 142.1342 $\left(\mathrm{C}_{7} \mathrm{H}_{16} \mathrm{~N}_{3}{ }^{+}\right)$; HRMS (ESI) negative ion: $m / z$ $170.9134 \quad\left(\mathrm{Co}(\mathrm{CO})_{4}^{-}\right), \quad 142.9196 \quad\left(\mathrm{Co}(\mathrm{CO})_{3}{ }^{-}\right), \quad 114.9249$ $\left(\mathrm{Co}(\mathrm{CO})_{2}^{-}\right)$.

3d $0.27 \mathrm{~g}$, 83\%; $T_{\mathrm{g}}$ : $-55^{\circ} \mathrm{C}$; thermal decomposition temperature: $202{ }^{\circ} \mathrm{C}$; selected $v_{\max } / \mathrm{cm}^{-1}(\mathrm{KBr}) 1879$ vs $\left(\mathrm{Co}(\mathrm{CO}) 4^{-}\right) ;{ }^{1} \mathrm{H}$ NMR (400 MHz, DMSO- $\left.d_{6}\right): \delta 7.82(\mathrm{~s}, 2 \mathrm{H}), 3.25(\mathrm{~d}, J=5.1 \mathrm{~Hz}$, $4 \mathrm{H}), 2.91$ (s, 6H), 1.59 (s, 6H); ${ }^{13} \mathrm{C}$ NMR (100 MHz, DMSO- $\left.d_{6}\right): \delta$ 160.4, 48.6, 39.3, 25.0, 23.3; HRMS (ESI) positive ion: $\mathrm{m} / \mathrm{z}$ $156.1489\left(\mathrm{C}_{8} \mathrm{H}_{18} \mathrm{~N}_{3}{ }^{+}\right)$; HRMS (ESI) negative ion: $m / z 170.9132$ $\left(\mathrm{Co}(\mathrm{CO})_{4}^{-}\right), 142.9204\left(\mathrm{Co}(\mathrm{CO})_{3}{ }^{-}\right), 114.9253\left(\mathrm{Co}(\mathrm{CO})_{2}^{-}\right)$.

\subsection{Catalytic activity of cobalt carbonyl ILs based on 1,1,3,3-tetra-alkylguanidine in the carbonylation of epoxide}

The catalytic activity of the cobalt carbonyl ILs based on 1,1,3,3-tetra-alkylguanidine in the reaction of ring-opening carbonylation of epoxides was investigated. In our test, we observed that the compounds $\mathbf{3 a - 3 d}$, especially $\mathbf{3 a}$, without the aid of a base additive, exhibited relatively good catalytic activity in the reaction of alkoxycarbonylation of epoxides (Scheme 2).

The reaction was conducted in a 50-mL stainless steel autoclave equipped with a stirring magnet. The reactor was charged with ethanol $(3.0 \mathrm{~mL})$, epoxide $(5.0 \mathrm{mmol})$, and catalyst $3 \mathbf{a}$ (3 mol\%). Then, the reactor was pressurized with 6.0 MPa CO and heated to $80^{\circ} \mathrm{C}$. After completion of the reaction, the autoclave was cooled with ice water and slowly depressurized to atmospheric pressure. The product mixture underwent simple flash column chromatography to dispose of the ILs catalyst and was then analyzed using gas chromatography (GC) and GC-MS.

The structures and purities of the products were fully characterized using NMR spectroscopy. Analytical data for these compounds are listed below.

Ethyl 3-hydroxybutyrate (4a). This compound was prepared using the general procedure described above and purified by flash column chromatography to give a colorless oil, $0.54 \mathrm{~g}, 81 \%$ yield. ${ }^{1} \mathrm{H}$ NMR (400 MHz, $\mathrm{CDCl}_{3}$ ): $\delta 4.31-4.05(\mathrm{~m}$, $3 \mathrm{H}), 2.79$ (s, 1H), 2.46 (qd, $J=16.4,6.1 \mathrm{~Hz}, 2 \mathrm{H}), 1.28(\mathrm{t}, J=7.1$ $\mathrm{Hz}, 3 \mathrm{H}$ ), 1.23 (d, $J=6.3 \mathrm{~Hz}, 3 \mathrm{H}$ ); ${ }^{13} \mathrm{C}$ NMR (100 MHz, $\left.\mathrm{CDCl}_{3}\right): \delta$ 173.0, 64.3, 60.7, 42.8, 22.4, 14.2.

Ethyl 3-hydroxyvalerate (4b). This compound was prepared using the general procedure described above and purified by flash column chromatography to give a colorless oil, $0.66 \mathrm{~g}$, $90 \%$ yield. ${ }^{1} \mathrm{H}$ NMR (400 MHz, $\left.\mathrm{CDCl}_{3}\right): \delta 4.16(\mathrm{q}, J=7.1 \mathrm{~Hz}, 2 \mathrm{H})$, 4.02-3.85 (m, 1H), 2.89 (s, 1H), 2.49 (dd, $J=16.4,3.1 \mathrm{~Hz}, 1 \mathrm{H})$, 2.38 (dd, $J=16.4,9.1 \mathrm{~Hz}, 1 \mathrm{H}), 1.62-1.39(\mathrm{~m}, 2 \mathrm{H}), 1.26(\mathrm{t}, J=7.1$ $\mathrm{Hz}, 3 \mathrm{H}), 0.95(\mathrm{t}, J=7.5 \mathrm{~Hz}, 3 \mathrm{H}) ;{ }^{13} \mathrm{C}$ NMR (100 MHz, $\left.\mathrm{CDCl}_{3}\right): \delta$

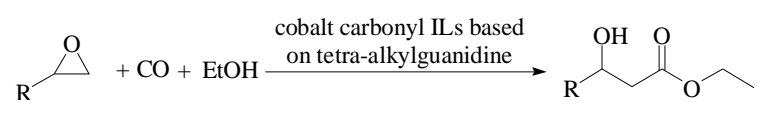

Scheme 2. Alkoxycarbonylation of epoxides.
173.1, 69.3, 60.6, 40.9, 29.4, 14.2, 9.8.

Ethyl 3-hydroxyheptanoate (4c). This compound was prepared using the general procedure described above and purified by flash column chromatography to give a colorless oil, $0.77 \mathrm{~g}$, 89\% yield. ${ }^{1} \mathrm{H}$ NMR (400 MHz, $\mathrm{CDCl}_{3}$ ): $\delta 4.15$ (q, $J=7.1$ $\mathrm{Hz}, 2 \mathrm{H}), 4.05-3.92(\mathrm{~m}, 1 \mathrm{H}), 2.92(\mathrm{~s}, 1 \mathrm{H}), 2.48$ (dd, $J=16.4,3.2$ $\mathrm{Hz}, 1 \mathrm{H}), 2.38$ (dd, $J=16.4,9.0 \mathrm{~Hz}, 1 \mathrm{H}), 1.56-1.43(\mathrm{~m}, 2 \mathrm{H})$, $1.42-1.34(\mathrm{~m}, 2 \mathrm{H}), 1.34-1.29(\mathrm{~m}, 2 \mathrm{H}), 1.26(\mathrm{dd}, J=8.9,5.4 \mathrm{~Hz}$, $3 \mathrm{H}), 0.92-0.86(\mathrm{~m}, 3 \mathrm{H}) ;{ }^{13} \mathrm{C}$ NMR (100 MHz, $\left.\mathrm{CDCl}_{3}\right): \delta 173.1$, 68.0, 60.6, 41.3, 36.2, 29.7, 27.6, 22.6, 14.1.

3-Hydroxyhept-6-enoic acid ethyl ester (4d). This compound was prepared using the general procedure described above and purified by flash column chromatography to give a colorless oil, $0.69 \mathrm{~g}$, $80 \%$ yield. ${ }^{1} \mathrm{H}$ NMR (400 $\mathrm{MHz}, \mathrm{CDCl}_{3}$ ): $\delta$ 5.91-5.67 (m, 1H), 5.12-4.92 (m, 2H), 4.23-4.07 (m, 2H), 4.07-3.92 (m, 1H), $3.04(\mathrm{~s}, 1 \mathrm{H}), 2.55-2.35(\mathrm{~m}, 2 \mathrm{H}), 2.28-2.01$ (m, 2H), 1.72-1.41 (m, 2H), 1.30-1.21 (m, 3H); ${ }^{13} \mathrm{C}$ NMR $(100$ $\left.\mathrm{MHz}, \mathrm{CDCl}_{3}\right): \delta 173.0,138.1,115.0,77.4,77.0,76.7,67.4,60.7$, $41.3,35.6,29.7,14.2$.

4-Butoxy-3-hydroxybutyric acid ethyl ester (4e). This compound was prepared using the general procedure described above and purified by flash column chromatography to give a colorless oil, $0.94 \mathrm{~g}$, $92 \%$ yield. ${ }^{1} \mathrm{H}$ NMR (400 $\mathrm{MHz} \mathrm{CDCl}_{3}$ ): $\delta$ 4.25-4.12 (m, 3H), 3.52-3.37 (m, 4H), 3.11 (d, $J=77.9 \mathrm{~Hz}, 1 \mathrm{H})$, $2.53(\mathrm{~d}, J=6.3 \mathrm{~Hz}, 2 \mathrm{H}), 1.61-1.51(\mathrm{~m}, 2 \mathrm{H}), 1.43-1.31(\mathrm{~m}, 2 \mathrm{H})$, $1.28(\mathrm{t}, J=7.1 \mathrm{~Hz}, 3 \mathrm{H}), 0.92(\mathrm{t}, J=7.4 \mathrm{~Hz}, 3 \mathrm{H}) ;{ }^{13} \mathrm{C}$ NMR $(100$ $\left.\mathrm{MHz}, \mathrm{CDCl}_{3}\right): \delta 172.2,73.7,71.3,67.2,60.7,38.3,31.7,19.3$, 14.2, 13.9 .

3-Hydroxy-4-phenoxybutyric acid ethyl ester (4f). This compound was prepared using the general procedure described above and purified by flash column chromatography to give a colorless oil, $0.94 \mathrm{~g}, 84 \%$ yield. ${ }^{1} \mathrm{H}$ NMR $(400 \mathrm{MHz}$, $\left.\mathrm{CDCl}_{3}\right): \delta 7.26(\mathrm{~s}, 2 \mathrm{H}), 7.00-6.95(\mathrm{~m}, 1 \mathrm{H}), 6.91(\mathrm{dd}, J=11.4,3.6$ $\mathrm{Hz}, 2 \mathrm{H}), 4.48-4.37(\mathrm{~m}, 1 \mathrm{H}), 4.23-4.16(\mathrm{~m}, 2 \mathrm{H}), 4.00(\mathrm{~d}, J=5.3$ $\mathrm{Hz}, 2 \mathrm{H}), 3.10$ (d, $J=33.6 \mathrm{~Hz}, 1 \mathrm{H}), 2.68$ (dd, $J=9.7,5.5 \mathrm{~Hz}, 2 \mathrm{H}$ ), 1.30-1.27 (m, 3H); ${ }^{13} \mathrm{C}$ NMR (100 MHz, $\left.\mathrm{CDCl}_{3}\right): \delta 172.1,158.4$, $129.5,121.2,114.6,70.6,66.8,60.9,38.1,14.2$.

4-Butyryloxy-3-hydroxybutyric acid ethyl ester (4g). This compound was prepared using the general procedure described above and purified by flash column chromatography to give a colorless oil, $0.86 \mathrm{~g}, 79 \%$ yield. ${ }^{1} \mathrm{H}$ NMR $(400 \mathrm{MHz}$, $\left.\mathrm{CDCl}_{3}\right): \delta 4.29(\mathrm{td}, J=11.7,6.1 \mathrm{~Hz}, 1 \mathrm{H}), 4.24-4.16(\mathrm{~m}, 2 \mathrm{H})$, 4.17-4.03 (m, 2H), 3.36-2.80 (m, 1H), 2.74-2.45 (m, 2H), 2.40-2.27 (m, 2H), 1.73-1.62 (m, 2H), 1.32-1.25 (m, 3H), 0.96 $(\mathrm{t}, J=7.4 \mathrm{~Hz}, 3 \mathrm{H}) ;{ }^{13} \mathrm{C} \mathrm{NMR}\left(100 \mathrm{MHz}, \mathrm{CDCl}_{3}\right): \delta 173.6,172.0$, $66.9,66.4,61.0,37.9,36.0,18.4,14.2,13.7$.

Ethyl-4-chloro-3-hydroxybutyrate (4h). This compound was prepared using the general procedure described above and purified by flash column chromatography to give a colorless oil, 0.58 g, $70 \%$ yield. ${ }^{1} \mathrm{H}$ NMR ( $\left.400 \mathrm{MHz}, \mathrm{CDCl}_{3}\right): \delta 4.30-4.22(\mathrm{~m}$, $1 \mathrm{H}), 4.22-4.13(\mathrm{~m}, 2 \mathrm{H}), 3.66-3.54(\mathrm{~m}, 2 \mathrm{H}), 3.14(\mathrm{~s}, 1 \mathrm{H})$, 2.68-2.56 (m, 2H), 1.35-1.20 (m, 3H); ${ }^{13} \mathrm{C}$ NMR $(100 \mathrm{MHz}$, $\left.\mathrm{CDCl}_{3}\right): \delta 171.8,68.0,61.0,48.1,38.5,14.1$.

Ethyl-3-hydroxy-3-phenyl propionate (4i). This compound was prepared using the general procedure described above and purified by flash column chromatography to give a colorless oil, 0.39 g, $40 \%$ yield. ${ }^{1} \mathrm{H}$ NMR (400 MHz, $\mathrm{CDCl}_{3}$ ): $\delta 4.30-4.22(\mathrm{~m}$, 
$1 \mathrm{H})$, 4.22-4.13 (m, 2H), 3.66-3.54 (m, 2H), $3.14(\mathrm{~s}, 1 \mathrm{H})$, 2.68-2.56 (m, 2H), 1.35-1.20 (m, 3H); ${ }^{13} \mathrm{C}$ NMR (100 MHz, $\left.\mathrm{CDCl}_{3}\right): \delta 172.4,142.5,128.6,127.8,125.7,70.3,60.9,43.4,14.2$.

3 -Hydroxy-4-phenylbutyric acid ethyl ester (4j). This compound was prepared using the general procedure described above and purified by flash column chromatography to give a colorless oil, $0.74 \mathrm{~g}, 71 \%$ yield. ${ }^{1} \mathrm{H}$ NMR (400 $\left.\mathrm{MHz} \mathrm{CDCl}_{3}\right): \delta$ 7.56-6.95 (m, 5H), 4.33-4.21 (m, 1H), 4.21-4.07 (m, 2H), 3.01 (d, $J=33.8 \mathrm{~Hz}, 1 \mathrm{H}), 2.87$ (dd, $J=13.6,7.1 \mathrm{~Hz}, 1 \mathrm{H}), 2.76$ (dd, $J=$ 13.6, $6.2 \mathrm{~Hz}, 1 \mathrm{H}), 2.58-2.35(\mathrm{~m}, 2 \mathrm{H}), 1.31-1.22(\mathrm{~m}, 3 \mathrm{H}) ;{ }^{13} \mathrm{C}$ NMR $\left(100 \mathrm{MHz}, \mathrm{CDCl}_{3}\right): \delta 172.7,137.7,129.5,128.5,126.6$, $69.1,60.7,43.0,40.5,14.2$.

\section{Results and discussion}

\subsection{Characterization of cobalt carbonyl ILs based on 1,1,3,3-tetra-alkylguanidine}

\subsubsection{Miscibility}

The miscibilities of the four compounds $\mathbf{3 a - 3 d}$ were qualitatively determined to be similar in several common solvents. They were all well dissolved in more polar organic solvents such as methanol, ethanol, dichloromethane, tetrahydrofuran, and acetone, whereas they were insoluble in some less polar solvents such as petroleum ether, hexane, and toluene, most likely because of the existence of the ionic bond [35]. However, none of the compounds could be dissolved in chloroform despite its polarity. In addition, all of the compounds were insoluble in water.

\subsubsection{IR studies}

The IR spectra of all four salts reveal a strong band at approximately $1880 \mathrm{~cm}^{-1}$ for the characteristic CO absorption, also indicating the presence of the $\mathrm{Co}(\mathrm{CO})_{4}{ }^{-}$anion [36]; however, the spectra also contain minor differences. With the lengthening of the alkyl chain, the $\mathrm{CO}$ absorption $\left(\mathrm{T}_{2}\right)$ band shifts to lower wavenumbers, indicting the effect of so-called interionic hydrogen bonding between ion pairs [22]. The bands at $\sim 3450 \mathrm{~cm}^{-1}$ also reflect intermolecular hydrogen bands. In each infrared spectrum of the four prepared compounds, the symmetry-forbidden $A_{1}$ bands at $\sim 2008 \mathrm{~cm}^{-1}$ are observed,

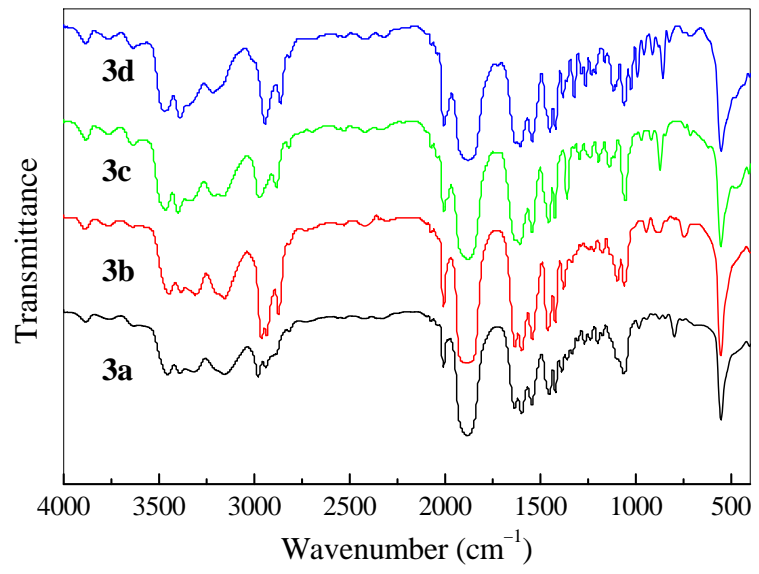

Fig. 1. IR spectra of $\mathbf{3 a - 3 d}$.
Table 1

$T_{\mathrm{g}}$ values of $\mathbf{3 a}-\mathbf{3 d}$.

\begin{tabular}{lcccc}
\hline Compound & 3a & 3b & 3c & 3d \\
\hline$T_{\mathrm{g}} /{ }^{\circ} \mathrm{C}$ & -77 & -65 & -60 & -55 \\
\hline
\end{tabular}

indicating a distortion of the anion $\operatorname{Co}(\mathrm{CO})_{4}^{-}$from ideal $\mathrm{T}_{\mathrm{d}}$ symmetry. This distortion could be caused by the hydrogen bonds [22,37-38], and the appearance of these forbidden bands provides a reliable measure to confirm the existence of these distortions in crystalline charge-transfer salts, which has been previously illustrated by Bockman et al. [37]. Moreover, the most distorted anion out of the four salts is apparent because of the close proximity of the anion/cation pairs (Fig. 1).

\subsubsection{Melting point and stability}

The thermal behavior of the four ILs salts $\mathbf{3 a - 3 d}$ was analyzed using DSC and TG-DSC techniques, and the $T_{\mathrm{g}}$ data are listed in Table 1. For all four compounds, the glass transition temperature was approximately $-60^{\circ} \mathrm{C}$, indicating that they are room-temperature ILs.

The thermal stability of the four compounds was also measured using thermogravimetric analysis. The TG-DSC curves (Fig. 2) reveal that the four ILs are quite robust and thermal stable, and their decomposition temperatures are high (approximately $200{ }^{\circ} \mathrm{C}$ ). It is clear that the thermal stability of compounds 3a-3d satisfies the requirements of most chemical reaction systems.

Because of the existence of interionic hydrogen bonding (which can be confirmed by the bands at $\sim 3450 \mathrm{~cm}^{-1}$ in the IR spectrum in Fig. 1) [22], the stability of compounds 3a-3d is much better than that of conventional $\mathrm{Co}(\mathrm{CO})_{4}^{-}$salts, such as $\mathrm{NaCo}(\mathrm{CO})_{4}$ and $\mathrm{KCo}(\mathrm{CO})_{4}$. After exposure to air for $24 \mathrm{~h}$ at room temperature, the physical appearances of compounds 3a-3d were unchanged. The IR spectra of compound 3a before the reaction and after 4 runs are presented in Fig. 3, and there are no obvious changes. The characteristic $\mathrm{CO}$ absorption band at $\sim 1860 \mathrm{~cm}^{-1}$ and symmetry-forbidden $\mathrm{A}_{1}$ band at $\sim 2008 \mathrm{~cm}^{-1}$ can still be observed in the IR spectra of compound 3a after 4 runs. However, the bands at 3300-3500 $\mathrm{cm}^{-1}$ show slight changes, which were most likely caused by the presence of a few impurities. Therefore, this result also demonstrates the stability of catalyst $\mathbf{3 a}$.

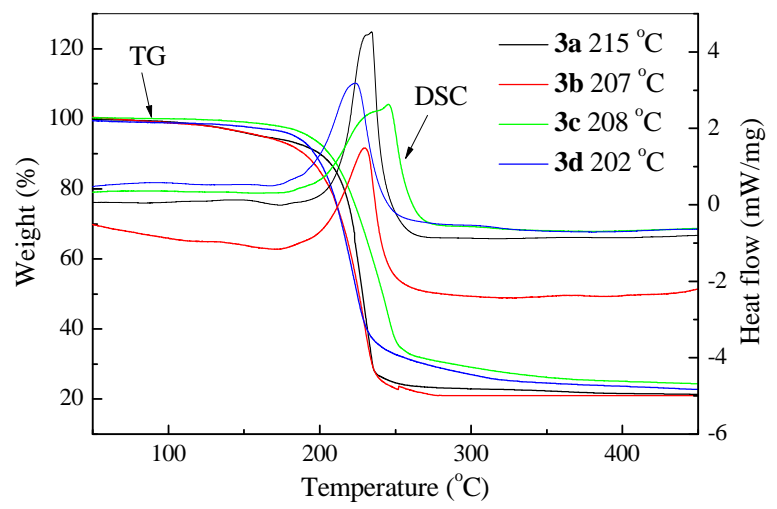

Fig. 2. TG-DSC curves of 3a-3d. 


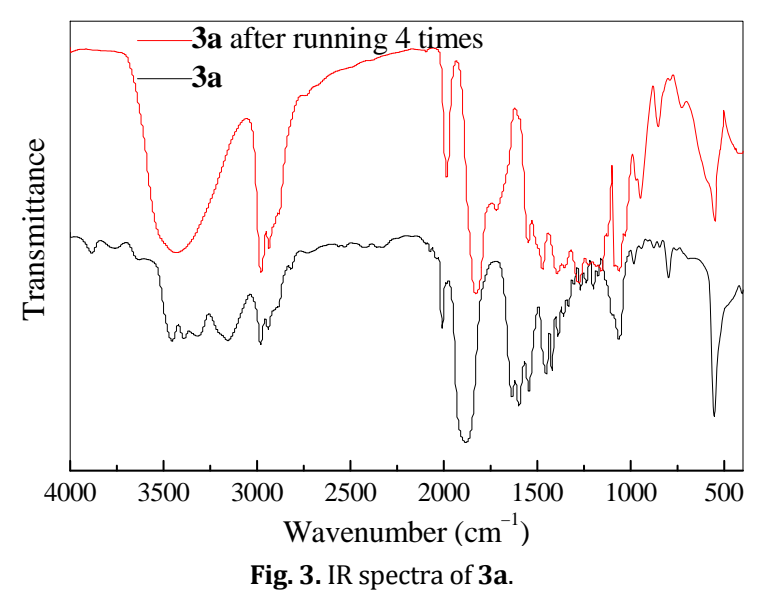

3.1.4. NMR studies

All four salts (3a-3d) exhibited similar ${ }^{1} \mathrm{H}$ and ${ }^{13} \mathrm{C}$ NMR chemical shifts compared with their corresponding halide precursors (2a-2d), which indicated that no major change occurred in the chemical structure of the cationic part of the compounds. Thus, the cationic part of the compounds was confirmed to exhibit the expected structure. In the ${ }^{1} \mathrm{H}$ NMR spectra, the peaks for the $1-\mathrm{H}$ of the $\mathrm{N}$ atoms and $1-\mathrm{H}$ of the $\mathrm{N}$-alkyls were shifted upfield compared with those of their corresponding halide precursors because of the effect of the interionic hydrogen bonding. In addition, the carbonyl carbon atoms were still not observed under normal conditions, as previously reported $[11,22]$, most likely because of the paramagnetism of the cobalt center.

\subsubsection{UV-Vis studies}

The UV-Vis absorption spectra for all four compounds 3a-3d in the region $200-700 \mathrm{~nm}$ were investigated in dichloromethane. The results are presented in Table 2. Data for $\mathrm{KCo}(\mathrm{CO})_{4}$ derived from the literature [22] are also listed for comparison. The spectra are clearly similar to that of $\mathrm{KCo}(\mathrm{CO}) 4$. According to the literature [22], the latter shows a major absorption band at $233 \mathrm{~nm}$ and a shoulder at $360 \mathrm{~nm}$, which is assigned as the internal charge-transfer absorption band ( $>$ $350 \mathrm{~nm}$ ). Compounds 3a-3d exhibit a similar absorption band at approximately $230 \mathrm{~nm}$, as observed in Table 2 . The characteristic $\mathrm{Co}(\mathrm{CO})_{4}^{-}$band at $\sim 230 \mathrm{~nm}$ persists, indicating the presence of $\mathrm{Co}(\mathrm{CO})_{4}^{-}$.

\subsubsection{HRMS (ESI) studies}

In the HRMS (ESI) spectra, the peaks of the cations and anions are observed, which strongly confirms the structure and purity of the expected compounds, except that in some cases, the cobalt tetracarbonyl anion tends to lose one or two carbonyls to afford $\mathrm{Co}(\mathrm{CO})_{3^{-}}$or $\mathrm{Co}(\mathrm{CO})_{2}-$.

\subsection{Catalytic performance of cobalt carbonyl ILs based on 1,1,3,3-tetra-alkylguanidine}

\subsubsection{Optimization of reaction conditions}

The catalytic activity of cobalt carbonyl ILs based on
Table 2

UV-Vis absorption bands of $\mathrm{KCo}(\mathrm{CO})_{4}$ and $\mathbf{3 a - 3 d}$ in dichloromethane.

\begin{tabular}{lc}
\hline Compound & UV-Vis absorption bands (nm) \\
\hline $\mathrm{KCo}(\mathrm{CO})_{4}$ & $233,360(\mathrm{sh})$ \\
3a & 229 \\
3b & 229 \\
3c & 229 \\
3d & 234 \\
\hline
\end{tabular}

1,1,3,3-tetra-alkylguanidine in the reaction of alkoxycarbonylation of propylene oxide (PO) was investigated. In addition, the reaction conditions were optimized (Table 3). Upon treating the substrate PO with 2 mol\% catalyst 3a-3d in ethanol under CO atmosphere, the desired product was obtained with little difference in conversion or selection (Table 3, entries 1-4). Compounds 3a-3d showed distinct catalytic activity, with that of 3a exhibiting the optimal activity. Moreover, good catalytic activity of 3a could be achieved when ethanol was used as both the reactant and solvent (Table 3, entries 5-7) without adding other solvents. The conversion of PO and yield of ethyl 3-hydroxybutyrate increased with increasing catalyst loading and changed slightly when the catalyst:PO ratio was greater than $3 \mathrm{~mol} \%$ (Table 3, entries 5 and 8-10). The effect of temperature on this reaction was significant (Table 3, entries 5 and 11-13). With increasing temperature, the PO conversion greatly increased; however, the selectivity to ethyl 3-hydroxybutyrate decreased when the temperature was above $80^{\circ} \mathrm{C}$ (Table 3 , entries 5 and 11-13). The conversion of PO and yield of ethyl 3-hydroxybutyrate increased with increasing CO pressure and changed slightly when the CO pressure was greater than $5 \mathrm{MPa}$ (Table 3, entries 12 and 14-16). In addition, the effect of time on this reaction should not be underestimated (Table 3, entries 16-18). The conversion of PO and yield of ethyl 3-hydroxybutyrate increased with increasing time. Fairly high conversion (99\%) and selectivity (98\%) could be obtained with optimal and relatively mild reaction conditions (Table 3, entry 19).

Moreover, the catalytic performance of 3a for the hydroesterification of PO was compared with that of a conventional catalytic system $\mathrm{Co}_{2}(\mathrm{CO})_{8}$ (Table 3, entry 20). It is apparent that the catalytic activity of $3 \mathbf{a}$ was better than that of $\mathrm{Co}_{2}(\mathrm{CO})_{8}$. The existence of 1,1-dimethyl-3,3-diethylguanidinium ${ }^{+}$appeared to assist the ring-opening process of the PO [23,28,30-32], and the introduction of the guanidinium ILs pattern to the catalyst not only prevented catalyst leaching but also increased the stability of the catalyst.

\subsubsection{Substrate scope of the terminal epoxide}

The ready alkoxycarbonylation of propylene oxide with catalyst 3a in ethanol under relatively mild reaction conditions motivated the study of the general range of this catalytic process for the synthesis of $\beta$-hydroxy esters. Thus, the scope of the substrate epoxides bearing alkyl, alkenyl, glycidyl, heteroatom, aryl, and alkyl-aryl groups for the reaction was explored. Generally, $\beta$-hydroxy esters were obtained in good yields. Terminal epoxides bearing simple alkyl and alkenyl groups reacted 
Table 3

Optimization of reaction conditions ${ }^{\text {a. }}$.

\begin{tabular}{|c|c|c|c|c|c|c|c|c|}
\hline Entry & Catalyst & $\begin{array}{c}\text { Catalyst/PO } \\
(\mathrm{mol} \%)\end{array}$ & Solvent & $\mathrm{T} /{ }^{\circ} \mathrm{C}$ & $P(\mathrm{CO}) / \mathrm{MPa}$ & $t / \mathrm{h}$ & $\begin{array}{c}\text { Conversion }^{\mathrm{b}} \\
(\%)\end{array}$ & $\begin{array}{c}\text { Selectivity } \\
(\%)\end{array}$ \\
\hline 1 & $3 \mathbf{a}$ & 2 & EtOH $(2 \mathrm{~mL})$ & 60 & 7 & 24 & 54 & 95 \\
\hline 2 & $3 b$ & 2 & EtOH $(2 \mathrm{~mL})$ & 60 & 7 & 24 & 50 & 91 \\
\hline 3 & $3 c$ & 2 & EtOH (2 mL) & 60 & 7 & 24 & 46 & 86 \\
\hline 4 & $3 d$ & 2 & EtOH (2 mL) & 60 & 7 & 24 & 35 & 85 \\
\hline 5 & $3 a$ & 2 & EtOH (3 mL) & 60 & 7 & 24 & 77 & 90 \\
\hline 6 & $3 a$ & 2 & EtOH $(0.5 \mathrm{~mL}), 1,4$-dioxane $(2.5 \mathrm{~mL})$ & 60 & 7 & 24 & 25 & 80 \\
\hline 7 & 3a & 2 & EtOH (0.5 mL), THF (2.5 mL) & 60 & 7 & 24 & 27 & 83 \\
\hline 8 & $3 a$ & 1 & EtOH (3 mL) & 60 & 7 & 24 & 46 & 85 \\
\hline 9 & $3 a$ & 3 & EtOH (3 mL) & 60 & 7 & 24 & 92 & 99 \\
\hline 10 & $3 a$ & 4 & $\mathrm{EtOH}(3 \mathrm{~mL})$ & 60 & 7 & 24 & 94 & 97 \\
\hline 11 & $3 \mathbf{a}$ & 2 & EtOH (3 mL) & 40 & 7 & 24 & 14 & 89 \\
\hline 12 & $3 a$ & 2 & EtOH $(3 \mathrm{~mL})$ & 80 & 7 & 24 & 97 & 95 \\
\hline 13 & $3 a$ & 2 & EtOH (3 mL) & 100 & 7 & 24 & 99 & 73 \\
\hline 14 & $3 a$ & 2 & $\mathrm{EtOH}(3 \mathrm{~mL})$ & 80 & 4 & 24 & 73 & 90 \\
\hline 15 & $3 a$ & 2 & EtOH (3 mL) & 80 & 5 & 24 & 82 & 93 \\
\hline 16 & $3 a$ & 2 & EtOH (3 mL) & 80 & 6 & 24 & 97 & 96 \\
\hline 17 & $3 a$ & 2 & EtOH (3 mL) & 80 & 6 & 8 & 35 & 89 \\
\hline 18 & $3 a$ & 2 & EtOH (3 mL) & 80 & 6 & 16 & 77 & 98 \\
\hline 19 & $3 a$ & 3 & EtOH (3 mL) & 80 & 6 & 24 & 99 & 98 \\
\hline 20 & $\mathrm{Co}_{2}(\mathrm{CO})_{8}$ & 3 & EtOH (3 mL) & 80 & 6 & 24 & 78 & 85 \\
\hline
\end{tabular}

a Reaction conditions: PO (5.0 mmol). ${ }^{\mathrm{b}}$ Determined by GC with internal standard method.

well (Table 4, entries 1-4). In addition, various glycidol ether-functionalized epoxides also showed good reactivity (Table 4, entries 5-7). Moreover, the epoxides bearing heteroatoms such as epichlorohydrin obtained general yields (Table 4, entry 8). In addition, aryl- and alkyl-aryl-functionalized epoxides are known to react slowly, thus affording lower yields. Fortunately, 2-phenylpropylene oxide and 3-phenylbutene 1,2-oxide produced relatively good yields compared with those reported in previous studies [25,39] (Table 4, entries 9 and 10).
However, the reaction of the cyclohexene oxide failed to afford the desired isolated product because of the poor reactivity (Table 4 , entry 11 ).

\subsubsection{Effect of configuration on ethoxycarbonylation of $P O$}

The effect of the configuration on ethoxycarbonylation of PO was also studied (Table 5) with this catalytic system. We observed that the configuration of the product was consistent with the substrate without racemization.

Table 4

Substrate scope of alkoxycarbonylation of terminal epoxides to $\beta$-hydroxy esters ${ }^{\text {a }}$.

\begin{tabular}{|c|c|c|c|c|c|c|c|c|c|}
\hline Entry & Epoxide & Product & $\begin{array}{c}\text { Conver- } \\
\text { sion }{ }^{\mathrm{b}}(\%)\end{array}$ & $\begin{array}{c}\text { Isolated } \\
\text { yield }(\%)\end{array}$ & Entry & Epoxide & Product & $\begin{array}{c}\text { Conver- } \\
\text { sion }^{b}(\%)\end{array}$ & $\begin{array}{c}\text { Isolated } \\
\text { yield (\%) }\end{array}$ \\
\hline 1 & & & 99 & 81 & 7 & & & 89 & 79 \\
\hline 2 & & $\mathrm{H} \quad \mathrm{O}$ & 98 & 90 & 8 & & & 87 & 70 \\
\hline 3 & & & 95 & 89 & 9 & & & 53 & 40 \\
\hline 4 & & & 89 & 80 & 10 & & & 85 & 71 \\
\hline 5 & & & 97 & 92 & 11 & & & 14 & 0 \\
\hline 6 & & & 91 & 84 & & & & & \\
\hline
\end{tabular}

a Reaction conditions: epoxide $(5.0 \mathrm{mmol}), 3 a(0.15 \mathrm{mmol})$ in ethanol $(3.0 \mathrm{~mL})$ under $\mathrm{CO} 6.0 \mathrm{MPa}$ at $80{ }^{\circ} \mathrm{C}$ for $24 \mathrm{~h}$.

${ }^{b}$ Determined by GC with internal standard method. 
Table 5

Effect of configuration on ethoxycarbonylation of $\mathrm{PO}$ a.

\begin{tabular}{|c|c|c|c|}
\hline Optical & $\begin{array}{c}\text { Conversion }{ }^{\mathrm{b}} \\
(\%)\end{array}$ & $\begin{array}{c}\text { Selectivity }{ }^{b} \\
(\%)\end{array}$ & $\begin{array}{c}\text { ee of the } \\
\text { productc (\%) }\end{array}$ \\
\hline Rac (ee $=0)$ & 99 & 98 & - \\
\hline$S(>99.9 \%)$ & 99 & 99 & $>99.9$ \\
\hline$R(>99.9 \%)$ & 98 & 99 & $>99.9$ \\
\hline
\end{tabular}

${ }^{a}$ Reaction conditions: PO $(5.0 \mathrm{mmol}), 3 \mathrm{3a}(0.15 \mathrm{mmol})$ in ethanol $(3.0$ $\mathrm{mL}$ ) under CO $6.0 \mathrm{MPa}$ at $80^{\circ} \mathrm{C}$ for $24 \mathrm{~h}$.

${ }^{\mathrm{b}}$ Determined by GC with internal standard method.

c Determined by GC with available capillary column Chirasil-Dex CB.

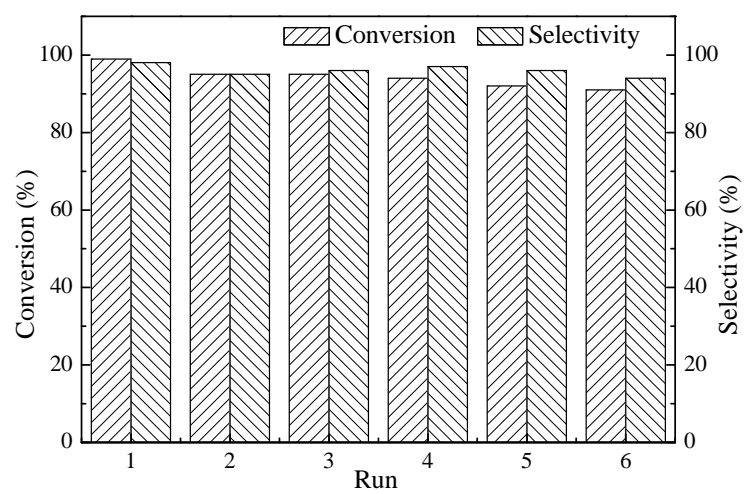

Fig. 4. Recyclability of $\mathbf{3 a}$ in the alkoxycarbonylation of PO. Reaction conditions: PO $(5.0 \mathrm{mmol}), 3 \mathrm{a}(0.15 \mathrm{mmol})$ in ethanol $(3.0 \mathrm{~mL})$ under CO $6.0 \mathrm{MPa}$ at $80^{\circ} \mathrm{C}$ for $24 \mathrm{~h}$.

\subsubsection{Catalyst reusability}

To evaluate the recyclability of the catalyst, the reusability of catalyst 3a was examined for the ethoxycarbonylation of PO, and the results are presented in Fig. 4. The catalyst 3a could be reused effectively at least six times with a small loss of selectivity and only a minor decrease in conversion. The catalytic system clearly exhibited good recyclability, which is considered a breakthrough that can mostly be attributed to the good stability of the catalyst.

\section{Conclusions}

A series of new cobalt carbonyl ILs based on 1,1,3,3-tetraalkylguanidine were designed, successfully synthesized, and characterized using various techniques. Because of the presence of interionic hydrogen bonds, compounds $\mathbf{3 a - 3 \mathbf { d }}$ are relatively stable when exposed to air. Moreover, the compounds exhibited remarkably good thermal stability. Notably, the catalyst 3a exhibited quite good catalytic activity and reusability in the reaction of alkoxycarbonylation of epoxides. The catalytic system could be reused at least six times with no significant decrease in selectivity or conversion. These new discoveries are beneficial for future investigations of these novel and interesting compounds.

\section{References}

[1] A. Paterno', F. D'Anna, C. G. Fortuna, G. Musumarra, Tetrahedron,
2016, 72, 3282-3287.

[2] R. Hayes, G. G. Warr, R. Atkin, Chem. Rev., 2015, 115, 6357-6426.

[3] R. Prado, X. Erdocia, G. F. De Gregorio, J. Labidi, T. Welton, ACS Sustain. Chem. Eng., 2016, 4, 5277-5288.

[4] D. R. MacFarlane, N. Tachikawa, M. Forsyth, J. M. Pringle, P. C. Howlett, G. D. Elliott, J. H. Davis, M. Watanabe, P. Simon, C. A. Angell, Energy Environ. Sci., 2014, 7, 232-250.

[5] D. Yang, D. L. Wang, H. Liu, X. L. Zhao, Y. Lu, S. J. Lai, Y. Liu, Chin. J. Catal., 2016, 37, 405-411.

[6] X. Q. Xiong, C. Yi, Q. Han, L. Shi, S. Z. Li, Chin. J. Catal., 2015, 36, 237-243.

[7] S. N. Korade, J. D. Patil, D. M. Pore, Monatsh. Chem., 2016, 147, 2143-2149.

[8] M. E. Moret, A. B. Chaplin, A. K. Lawrence, R. Scopelliti, P. J. Dyson, Organometallics, 2005, 24, 4039-4048.

[9] P. J. Dyson, Appl. Organometal. Chem., 2002, 16, 495-500.

[10] H. Schottenberger, K. Wurst, U. E. I. Horvath, S. Cronje, J. Lukasser, J. Polin, J. M. McKenzie, H. G. Raubenheimer, Dalton Trans., 2003, 4275-4281.

[11] R. J. C. Brown, P. J. Dyson, D. J. Ellis, T. Welton, Chem. Commun., 2001, 1862-1863.

[12] D. Kim, Y. Moon, D. Ji, H. Kim, D. Cho, ACS Sustain. Chem. Eng., 2016, 4, 4591-4600.

[13] T. Welton, Coord. Chem. Rev., 2004, 248, 2459-2477.

[14] Z. F. Fei, T. J. Geldbach, D. B. Zhao, P. J. Dyson, Chem. Eur. J., 2006, $12,2122-2130$.

[15] N. Komine, S. Tanaka, S. Tsutsuminai, Y. Akahane, M. Hirano, S. Komiya, Chem. Lett., 2004, 33, 858-859.

[16] D. Ardura, R. Lopez, J. Org. Chem., 2007, 72, 3259-3267.

[17] Y. T. Vigranenko, Petrol. Chem., 2001, 41, 121-125.

[18] T. L. Church, C. M. Byrne, E. B. Lobkovsky, G. W. Coates, J. Am. Chem. Soc., 2007, 129, 8156-8162.

[19] Z. M. Guo, H. S. Wang, Z. G. Lv, Z. H. Wang, T. Nie, W. W. Zhang, J. Organometal. Chem., 2011, 696, 3668-3672.

[20] L. Magna, S. Harry, A. Faraj, H. Olivier-Bourbigou, Oil Gas Sci. Technol., 2013, 68, 415-428.

[21] A. Polas, J. D. E. T. Wilton-Ely, A. M. Z. Slawin, D. F. Foster, P. J. Steynberg, M. J. Green, D. J. Cole-Hamilton, Dalton Trans., 2003, 4669-4677.

[22] F. G. Deng, B. Hu, W. Sun, J. Chen, C. G. Xia, Dalton Trans., 2007, 4262-4267.

[23] Z. G. Lv, H. S. Wang, J. A. Li, Z. M. Guo, Res. Chem. Intermed., 2010, $36,1027-1035$.

[24] J. E. Dengler, A. Doroodian, B. Rieger, J. Organometal. Chem., 2011, 696, 3831-3835.

[25] S. E. Denmark, M. Ahmad, J. Organometal. Chem., 2007, 72, 9630-9634.

[26] J. H. Liu, H. Wu, L. W. Wu, J. Chen, C. G. Xia, J. Mol. Catal. A, 2007, 269, 97-103.

[27] J. Huang, T. Jiang, H. X. Gao, B. X. Han, Z. M. Liu, W. Z. Wu, Y. H. Chang, G. Y. Zhao, Angew. Chem. Int. Ed., 2004, 43, 1397-1399.

[28] T. Chang, X. R. Gao, L. Bian, X. Y. Fu, M. X. Yuan, H. W. Jing, Chin. J. Catal., 2015, 36, 408-413.

[29] P. Gros, P. Le Perchec, J. P. Senet, J. Organometal. Chem., 1994, 59, 4925-4930.

[30] T. L. Church, Y. D. Y. L. Getzler, G. W. Coates, J. Am. Chem. Soc., 2006, 128, 10125-10133.

[31] Z. Hoštálek, [PhD Dissertation], Université de Bordeaux, Bordeaux, 2016.

[32] J. H. Liu, J. Chen, C. G. Xia, J. Mol. Catal. A, 2006, 250, 232-236.

[33] R. B. King, Transition-Metal Compounds, Academic Press, 1965.

[34] S. H. Li, Y. J. Lin, J. G. Cao, S. B. Zhang, J. Org. Chem., 2007, 72, 


\title{
Graphical Abstract
}

Chin. J. Catal., 2017, 38: 805-812 doi: 10.1016/S1872-2067(17)62824-9

\section{Cobalt carbonyl ionic liquids based on the \\ 1,1,3,3-tetra-alkylguanidine cation: Novel, highly efficient, and reusable catalysts for the carbonylation of epoxides}

Wei Zhang, Feng Han, Jin Tong, Chungu Xia, Jianhua Liu * Lanzhou Institute of Chemical Physics, Chinese Academy of Sciences; University of Chinese Academy of Sciences

A series of novel cobalt carbonyl ionic liquids based on 1,1,3,3-tetra-alkylguanidine were synthesized. The catalytic performance of these compounds was investigated in the carbonylation of epoxides, with $\mathbf{3 a}$ exhibiting the best catalytic activity and recyclability.

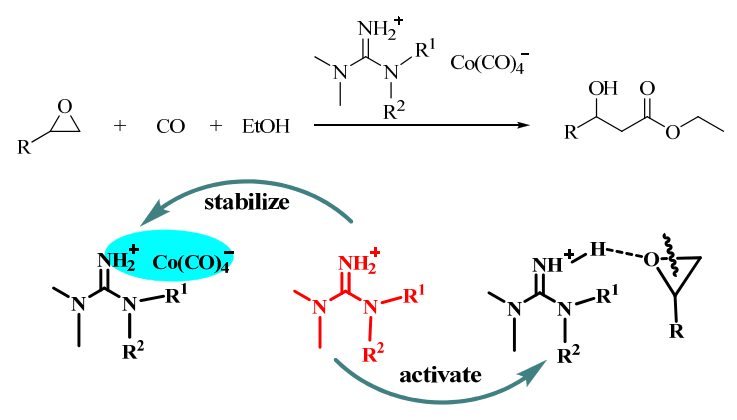

4067-4072.

[35] Z. G. Lv, Y. F. Jiang, C. Zhou, Z. M. Guo, X. L. Ma, Q. Chen, T. Nie, H. B. Song, J. Mol. Catal. A, 2016, 415, 89-95.

[36] J. A. R. Schmidt, E. B. Lobkovsky, G. W. Coates, J. Am. Chem. Soc., 2005, 127, 11426-11435.

[37] T. M. Bockman, J. K. Kochi, J. Am. Chem. Soc., 1989, 111,
4669-4683.

[38] W. F. Edgell, M. T. Yang, N. Koizumi, J. Am. Chem. Soc., 1965, 87, 2563-2567.

[39] A. Hamasaki, A. Muto, S. Haraguchi, X. H. Liu, T. Sakakibara, T. Yokoyama, M. Tokunaga, Tetrahedron Lett., 2011, 52, 6869-6872.

\section{1,1,3,3-四烷基胍羰基钴离子液体: 高效可循环利用的环氧化合物 羰基化反应催化新材料}

\author{
张 伟 ${ }^{\mathrm{a}, \mathrm{b}}$, 韩 峰 ${ }^{\mathrm{a}}$, 童 进 ${ }^{\mathrm{a}}$, 夏春谷 ${ }^{\mathrm{a}}$, 刘建华 ${ }^{\mathrm{a}, *}$ \\ a 中国科学院兰州化学物理研究所羰基合成与选择氧化国家重点实验室, 甘肃兰州 730000 \\ 中国科学院大学, 北京 100049
}

\begin{abstract}
摘要: 离子液体因其所独有的物理化学性质如蒸气压低、热稳定性好以及结构和性能的可调性等优点而备受关注. 四羰基 钴阴离子是多种重要均相催化反应的催化活性物种, 含有四羰基钴阴离子的金属有机离子液体有效结合了羰基金属和离 子液体各自的特点和优势, 作为一类新颖而且重要的功能化离子液体, 受到国内外研究者的青崃. 2001年, Dyson等首次报 道了一种室温下为液态的羰基钴金属有机离子液体 [bmim] [Co(CO) 4 , 为四羰基钴阴离子离子液体的研究开创了先河. 此 后,有关羰基钴金属有机离子液体的催化应用研究也相继报道. 目前 $[\mathrm{CnPy}]\left[\mathrm{Co}(\mathrm{CO})_{4}\right]$ 以及 $[\mathrm{bmim}]\left[\mathrm{Co}(\mathrm{CO})_{4}\right]$ 在环氧化合物的 羰基化反应中已有报道, 但该类催化剂的催化活性特别是循环使用性能有待进一步提高.

胍盐具有阳离子电荷分散程度高、热稳定性和化学稳定性高、三个氮原子上的基团可以调节等特点, 使得胍盐离子液 体的设计、合成和应用研究受到国内外学者关注. 由于其自身结构特点,氮原子上有取代氢可以和含 $F, O, N$ 底物作用形成 氢键, 并且氮原子上取代烷基之间作用使阳离子的平面结构发生变化, 使得与三个氮原子相连的碳原子处于缺电子状态, 使 阳离子表现出Lewis酸性. 所以其在环氧化合物氢酯基化反应中可起到稳定四羰基钴阴离子以及活化环氧化合物的作用.

基于此, 本文以较高收率合成了四种新型的1,1,3,3-四烷基胍羰基钴金属有机离子液体：1,1-二甲基-3,3-二乙基胍羰基 钴(3a), 1,1-二甲基-3,3-二正丁基胍羰基钴(3b), 1,1-二甲基-3,3-四亚甲基胍羰基钴(3c), 1,1-二甲基-3, 3-五亚甲基胍羰基钴 (3d). 通过红外光谱、紫外-可见光谱、 ${ }^{1} \mathrm{H}$ 核磁共振谱、 ${ }^{13} \mathrm{C}$ 核磁共振谱、高分辨质谱、差示量热扫描仪和热重分析对该类 化合物进行了结构确认及性质研究. 这四种催化剂, 特别是 $3 a$, 在环氧化合物的氢酯基化反应中表现出优异的催化性能, 在 无需任何助剂的情况下具有较好的催化活性及底物适用性. 此外, 以不同构型的环氧丙烷为反应底物, 氢酯基化反应结果显 示: 在该催化体系作用下,产物的构型与底物保持一致,没有发生消旋. 尤其值得指出的是,催化剂3a在环氧丙烷的氢酯基化 反应中表现出了优异的循环稳定性能, 在循环使用6次后依然可以获得较好的转化率(91\%)和选择性(94\%).
\end{abstract}

关键词：羰基钴离子液体；羊炭基化反应；环氧化合物；四烷基胍；循环稳定性

收稿日期: 2017-01-26. 接受日期: 2017-03-23. 出版日期: 2017-05-05.

*通讯联系人. 电话: (0931)4968286; 传真: (0931)8277088; 电子信箱: jhliu@licp.cas.cn

基金来源：国家自然科学基金(21373248, 21673260, 21133011).

本文的英文电子版由Elsevier出版社在ScienceDirect上出版(http://www.sciencedirect.com/science/journal/18722067). 